\title{
Marketing of Higher Education Services in India: A Critical Study
}

\author{
E.Thangasamy \\ Research Scholar, Department of Commerce, Nagaland University, Lumami
}

\begin{abstract}
Education is a crucial input for development of any nation. Higher Education Institutions, particularly while imparting knowledge and skills to the citizens, play a key role to accelerate the pace of developmental process. India has also been striving very hard to achieve its educational objectives for attaining its overall growth and development since independence. Hence, successful marketing of the invaluable educational service in home country and abroad by providing quality education to the prospective customers becomes very essential as they will act as producers in the days to come. Development of ICT in Education has also been constantly facilitating the smooth flow and exchange of educational products between the educational institutions and the aspiring learners.

This paper is an attempt to evaluate the status and trend of Higher Education System in India and suggest appropriate measures to improve the quality of Education and Research in order to accomplish its broader goals by satisfying the aspiring mass in the long run.

Key words: Education, educational objectives, educational prosperity, ICT in Education
\end{abstract}

\section{Introduction:}

Globally, in any developing country including India, education plays a vital role in its socio-economic development. Human capital is created, being a crucial input to economic development, through investment in education. Particularly the role and trend of higher education are changing worldwide with the development of technology at a faster rate, especially in the public sector. Education was, thus, believed to have been bypassed by the miracle of the market and is an instance of what Dreze and Sen (1998) call a market-excluding arrangement, rather than a market-complementary arrangement. Contrarily, developed countries have been able to have market-complementary arrangements in education as a result of which widespread literacy levels have been achieved. At the same time, the high literacy levels in the market -friendly western countries and the liberalized Asian economies were attained following the active state intervention and therefore the private sectors have come to play an increasingly more important role.

India has a strong tradition of higher education since ancient times. However, an emphasis on scientific enquiry came to our country only with the British. The first college imparting western education in India was established in Serampore in Bengal in 1818. Further, the social reforms movement of the $18^{\text {th }}$ century also accelerated the process of setting up of modern Universities and Colleges. Three Central Universities of Calcutta, Bombay and Madras were set up in the year, 1857, having 27 affiliated colleges. Then, more Universities and colleges were set up. In India, there were 19 Universities in 1947.

However, the public expenditure on education is only about $3 \%$ of the GNP. Rather, only $0.37 \%$ GDP is spent on higher Education and this has even been falling in recent years. Now, ICT in Education has started playing a major role in the exchange of knowledge and skills between the educational service providers and beneficiaries. However, further research is required to assess as to whether we are in the right direction to achieve the broader goals of education of our country by ensuring quality education.

This paper attempts to study the status of higher education in India as compared with other developing countries in the world, analyze the trend in growth of Higher Education system and measure the quality of Higher Education service. The paper is based purely on secondary data. The data is collected from the UGC websites, Government reports etc., Appropriate statistical tools are used for analysis and interpretation of the data to draw a meaning inference.

\section{SIGNIFICANCE OF HIGHER EDUCATION:}

Human capital is an input for economic development. The issue was raised and advocated in 1976 by Adam Smith. While explaining the root causes of affluence of nations, he identified and emphasized two factors; one was the importance of economies of scale and another was the importance of skill formation and human qualities. The second factor has become popular today as 'human capital'. Therefore, the comparative advantage in human skill and knowledge that gives the countries an edge while trading with others, rather than just a difference in physical endowments and the quantity of factors of production. The latter interpretation of gains from trade is the one given by the economists of the classical tradition such as David Ricardo. 
Hence, the crucial link between the human capital and economic prosperity implies that we have to look at the role of public policy in expanding educational arena and promotion of conducive learning achievement. When we talk about education, the issue of provision is closely linked to the nature of the service. i.e. whether education is a public good or a merit good and how to ensure adequate provision.

\section{CURRENT STATUS OF HIGHER EDUCATION SYSTEM IN INDIA:}

In 1980, there were 132 Universities and 4738 colleges in the country. They were enrolling about 5 per cent of the eligible age group in higher education. But, at present, our country has the third largest higher education system in the world after USA and the China in terms of enrolment. India is, however, the largest higher education system in the world with 17973 institutions (348 Universities and 17625 Colleges). It means that the average number of students per educational institution in India is also lower than that in China and USA.

At present, when we look at the situation in our country, with the assistance of ICT, India has been growing further as one of the largest higher education systems in the world, with 25.9 million students enrolled in more than 45000 degree colleges and diploma institutions in the country. According to the UGC Report, 2011, there are 634 degree awarding institutions (Universities) and 33,023 Colleges (averaging 50 colleges per University) in India. Of them, 100 are private Universities. It has also witnessed high growth particularly in the last decade, with the enrolment of the students increasing at a CAGR of $10.8 \%$ and institutions at CAGR of $9 \%$. In India, the following types of institutions are imparting higher education;

- Universities and Government

- Private Universities

- Deemed Universities (Unaided)

- Deemed Universities(Aided)

- Colleges under Government

- Private Colleges (Unaided)

- Private Colleges(Aided)

- Distance Learning

- Non-University Sector (Industrial Training Institutes and Polytechnics)

- Foreign Institutions

Between 1987 and 1993, the student enrolment has grown at an estimated rate of 7 per cent. On contrary, the rate of growth has now declined to 5.5 per cent. There are about 10.5 million students enrolled in all higher education institutions, with the teachers numbering around 321000. Despite this phenomenal growth, the total enrolment forms only about 11 per cent of the relevant age-group (17-23) population.

TABLE 1 : GROWTH OF HIGHER EDUCATIONAL INSTITUTIONS AND ENROLMENT IN INDIA

\begin{tabular}{|l|l|l|l|l|}
\hline Year & Universities & Colleges & $*$ Total HEIs & Enrolment (in Million) \\
\hline $1947-48$ & 20 & 496 & 516 & 0.2 \\
\hline $1950-51$ & 28 & 578 & 606 & 0.2 \\
\hline $1960-61$ & 45 & 1,819 & 1,864 & 0.6 \\
\hline $1970-71$ & 93 & 3,277 & 3,370 & 2.0 \\
\hline $1980-81$ & 123 & 4,738 & 4,861 & 2.8 \\
\hline $1990-91$ & 184 & 5,748 & 5,932 & 4.4 \\
\hline $2000-01$ & 266 & 11,146 & 11,412 & 8.8 \\
\hline $2005-06$ & 348 & 17,625 & 17,973 & 10.5 \\
\hline
\end{tabular}

- $\quad$ HEIs - Higher Educational Institutions

Source: Report of Trade Policy Division, Department of Commerce, Government of India, 2006

Table 1 exhibits that the trend of growth of higher educational institutions and enrolment have been constantly increasing right from independence in 1947. The number of Universities have multiplied more than 17 times from 1947 (just 20 to 348) till 2006. Similarly, the colleges have also increased more than 35 times numbering from 516 to 17,973 . The total number of Higher educational institutions have increased from 516 to 17973 indicating about 34 times as compared with the year 1947. Enrolment of students had augmented ranging from 0.2 million to 10.5 million which is more than 52 times comparatively. Thereafter, the growth of enrolment in these institutions has been increasing subsequently to 35.9 million during XIth Plan which continues to grow during the current XIIth plan too. Undoubtedly, the ICT has been facilitating the providers of education and the learners for smooth flow and exchange of knowledge between them. Offering courses and taking admissions, conducting examinations and evaluations, publishing results and seeking employment are some of the transactions being transacted online with the assistance of ICT. 
Marketing Of Higher Education Services In India: A Critical Study

TABLE 2: TYPOLOGY AND GROWTH TRENDS IN HIGHER EDUCATIONAL INSTITUTIONS

\begin{tabular}{|c|c|c|c|c|c|}
\hline Type & Ownership & Financing & $\begin{array}{ll}\text { Number } & \text { of } \\
\text { Institutions* }\end{array}$ & $\begin{array}{ll}\text { Number } & \text { of } \\
\text { Students* } & \end{array}$ & Growth Trends \\
\hline $\begin{array}{l}\text { Universities under } \\
\text { the Government }\end{array}$ & Public & Public & 240 & $1,000,000$ & Not growing \\
\hline Private Universities & Private & Private & 7 & 10,000 & $\begin{array}{l}\text { Emerging on the } \\
\text { scene }\end{array}$ \\
\hline $\begin{array}{l}\text { Deemed Universities } \\
\text { (Aided) }\end{array}$ & Private or Public & Public & 38 & 40,000 & Growing slowly \\
\hline $\begin{array}{l}\text { Deemed Universities } \\
\text { (Unaided) }\end{array}$ & Private & Private & 63 & 60,000 & Growing rapidly \\
\hline $\begin{array}{l}\text { Colleges under the } \\
\text { Government }\end{array}$ & Public & Public & 4,225 & $2,750,000$ & Not growing \\
\hline $\begin{array}{l}\text { Private } \\
\text { Colleges(Aided) }\end{array}$ & Private & Public & 5,750 & $3,450,000$ & Not growing \\
\hline $\begin{array}{ll}\begin{array}{l}\text { Private } \\
\text { (Unaided) }\end{array} & \text { Colleges } \\
\end{array}$ & Private & Private & 7,650 & $3,150,000$ & Growing rapidly \\
\hline Foreign Institutions & Private & Private & 150 & 8,000 & $\begin{array}{l}\text { Emerging on the } \\
\text { scene }\end{array}$ \\
\hline Total & & & 18,123 & $10,468,000$ & \\
\hline
\end{tabular}

Source: PawanAgarwal “Higher Education in India: The Need for Change”. ICRIER Working Paper, June 2006

Table 2 exhibits that the Deemed Universities (Unaided) and Private Colleges are growing rapidly whereas the Deemed Universities (Aided) are growing slowly. Presently, it has been found that private institutions account for $64 \%$ of the total institutions $59 \%$ of the enrolment of the country. Surprisingly, the Universities and Colleges under the Government and the Private Colleges (Aided ) are not growing. Simultaneously, Private Universities and Foreign Institutions are emerging on the scene. Here, the emerging question in the minds of the educators and policy makers today is to know and appraise as to whether we are progressing educationally in the right direction to attain the broader goals of education with the use of ICT.

TABLE 3: GROWTH IN ENROLMENT, ENROLMENT RATIO GNP PER CAPITA (SELECTED COUNTRIES)

\begin{tabular}{|l|l|l|l|l|l|}
\hline Country & \multicolumn{2}{|l|}{ Enrolment (in millions) } & Increase \% & GER-2001 \% & $\begin{array}{c}\text { GNP } \\
\text { (US Dollar), 2001 }\end{array}$ \\
\hline & $\mathbf{1 9 9 0 - 9 1}$ & $\mathbf{2 0 0 1 - 0 2}$ & & & \\
\hline USA & 13.1 & 15.93 & 16.2 & 81 & 34,280 \\
\hline China & 3.82 & 12.14 & 217.7 & 13 & 890 \\
\hline Japan & 2.90 & 3.97 & 36.8 & 49 & 35,610 \\
\hline India & $\mathbf{4 . 9 5}$ & $\mathbf{1 0 . 5 8}$ & $\mathbf{1 1 3 . 6}$ & $\mathbf{1 1}$ & $\mathbf{4 6 0}$ \\
\hline UK & 1.26 & 2.24 & 78.1 & 64 & 25,120 \\
\hline France & 1.70 & 2.03 & 19.4 & 54 & 22,730 \\
\hline Italy & 1.45 & 1.85 & 27.7 & 53 & 19,390 \\
\hline Brazil & 1.54 & 3.13 & 103.0 & 18 & 3,070 \\
\hline Indonesia & 1.59 & 3.18 & 99.7 & 15 & 690 \\
\hline Philippines & 1.71 & 2.47 & 44.3 & 31 & 1,030 \\
\hline Australia & 0.49 & 0.87 & 79.1 & 65 & 19,900 \\
\hline Malaysia & 0.12 & 0.56 & 358.9 & 27 \\
\hline
\end{tabular}

Source :PawanAgarwal "Higher Education in India: The Need for Change”. ICRIER Working Paper, June 2006

Table 3 exhibits that the enrolment of students in Higher Educational Institutions has increased (113.6\%)from 4.95 million during 1990--2002 to 10.58 .

Further, a recent McKinsey-NASSCOM study has shown that the total addressable global offshoring market is approximately US dollar 300 billion, of which US dollar 110 billion will be offshored by 2010 . India has the potential to capture about $50 \%$ of this market and in the process generate direct employment for about 2.3 million people and indirect employment for about 6.5 million people. However, high quality manpower would be required for such jobs. The Gross Enrolment ratio during the XIth five year plan (2007-2011) was $17.9 \%$ from $12,3 \%$ in the beginning of the period. During the period, 2010-2011, the growth stands at 1,69,75,000 that has almost doubled in the last decade, according to the UGC Report, 2011. 
Marketing Of Higher Education Services In India: A Critical Study

\section{TABLE 4: EXPENDITURE ON HIGHER EDUCATION}

\begin{tabular}{|l|l|l|l|}
\hline Country & $\begin{array}{l}\text { \% of GDP on Higher } \\
\text { Education }\end{array}$ & $\begin{array}{l}\text { Public expenditure on higher } \\
\text { education per student in } \\
\text { Dollar (2002/03) }\end{array}$ & $\begin{array}{l}\text { GDP per capita, 2002 (US } \\
\text { Dollar) }\end{array}$ \\
\hline USA & 1.41 & 9,629 & 36,006 \\
\hline China & 0.50 & 2,728 & 989 \\
\hline Japan & 0.54 & 4,830 & 31,407 \\
\hline India & $\mathbf{0 . 3 7}$ & $\mathbf{4 0 6}$ & $\mathbf{4 8 7}$ \\
\hline Germany & 1.13 & 11,948 & 24,051 \\
\hline UK & 1.07 & 8,502 & 26,444 \\
\hline France & 0.99 & 8,010 & 24,061 \\
\hline Italy & 0.87 & 7,491 & 20,528 \\
\hline Brazil & 0.91 & 3,986 & 2,593 \\
\hline Russia & 0.62 & 1,024 & 2,405 \\
\hline Canada & 1.88 & 15,490 & 22,777 \\
\hline Korea & 0.34 & 1,046 & 10,006 \\
\hline Indonesia & 0.28 & 666 & 817 \\
\hline Philippines & 0.43 & 625 & 975 \\
\hline Australia & 1.19 & 7,751 & 20,822 \\
\hline Malaysia & 2.70 & 11,790 & 3,905 \\
\hline
\end{tabular}

Source: UNESCO Institute of Statistics (UIS).

Table 4 exhibits that the public expenditure incurred ( 15490 Dollar) on higher education is the highest in Canada followed by Germany (11,948 US Dollar)and Malasia (11,790 US Dollar). The expenditure incurred by the remaining selected countries remains below 10000 Dollars. However, the analysis of the share of GDP per capita on the expenditure indicates that the USA tops the position having 36006 US dollars whereas India is at the bottom on the line having only 487 US dollars. In 2009, the expenditure in India stood $13.63 \%$ of the public expenditure and $3.77 \%$ of the GDP. Out of its total expenditure, the Higher Education got $32.3 \%$. Here, it may be even appropriate to contemplate whether the right product mix in education is provided to the customers (students) at affordable costs by keeping its quality intact. Still, the quality of education and research in India needs to be improved a lot so as to enable us to compete with global educational markets.

\section{MAJOR CHALLENGES IN EDUCATION SERVICES IN INDIA:}

The following are the major challenges in expansion, excellence and equity while marketing of higher educational services;

$>$ India's GER of $16 \%$ was much below the world average of $27 \%$ as well as that of other emerging countries such as China (26\%) and Brazil (36\%) in 2010.

$>$ There is a faculty shortage of $40 \%$ and $35 \%$ in the Central and State Universities respectively.

$>$ On the basis of NAAC accreditation, $62 \%$ of the Universities and $90 \%$ of the Colleges are below average in 2010.

$>$ India's relative citation impact is half the world average.

$>$ There is a wide disparity in the GER of higher education across the State and the Gross Attendance Ratio(GAR) in Urban and Rural Areas and Gender-Community wise.

$>$ Inter-State disparity is $47.9 \%$ in Delhi vs $9 \%$ in Assam.

$>$ Urban-Rural Divide is $30 \%$ in Urban areas vs $11.1 \%$ in Rural areas.

$>$ Differences across communities are $14.8 \%$ for OBCs, $11,6 \%$ for SCs, $7.7 \%$ for STs and $9.6 \%$ for Muslims.

$>$ Gender disparity is $15.2 \%$ for females vs $19 \%$ for males.

\section{BARRIERS IN MARKETING OF EDUCATIONAL SERVICES:}

In the process of marketing of educational services abroad, the following are some of the key impediments in general which act as trade barriers in cross border supply;

$>$ Lack of opportunity to qualify as degree awarding institution.

$>$ Excessive restrictions on imports of the educational materials.

$>$ Irrelevant restrictions on electronic transmission of course contents.

> Mandatory requirement to involve local partners while entering into and exiting from joint ventures.

$>$ Nationality requirements.

$>$ Restrictions on recruitment of foreign teachers.

$>$ Providing subsidies solely to local institutions.

$>$ Government Monopolies.

> Failure to understand the complex link between ICTs and Educational environment. Likewise, certain barriers also exist in the consumption process of this educational service abroad;

$>$ Strict restrictions on employment of the students (consumers) during their study. 
$>$ Recognition of innovative educational qualifications by other countries.

$>$ Quota system limiting the international students as a whole and also at a particular institutional level.

$>$ Restrictions such as visa requirements, foreign currency, exchange controls etc., on entry and temporary stay of students.

Hence, in order to bring about an improvement in trading of these educational services, many countries such as USA, Australia, New Zealand, Japan etc., have been constantly initiating specific negotiation proposals before the World Trade Organization (WTO) from time to time.

\section{MEASURES TO IMPROVE HIGHER EDUCATION SERVICES:}

In India, while marketing the higher educational services effectively, the following points deserve due consideration;

$>$ Quality of education and research activities may be encouraged and improved.

$>$ Interests of the consumers (students) may be protected by providing the facilities according to their diverse needs.

$>$ International equivalence of degrees and diplomas may be ensured.

$>$ Such diversified requirements of the consumers may be taken into consideration domestically and internationally to satisfy them.

$>$ Information network on higher education may be used optimally to deliver the service.

$>$ Merit-based student financing should be encouraged.

$>$ Conducive research environment should be created.

$>$ High quality faculty and improved technology for delivery of education should be ensured.

$>$ Employability has to be ensured by making the educational system relevant to reality.

$>$ Appropriate marketing mix in terms of courses, fees, channel of delivery and promotion has to be designed to attract more talents.

$>$ Institutions such as UGC, AICTE, NCTE etc., may shoulder greater responsibilities to ensure the quality in Education and Research in Higher Education system through constant monitoring and evaluation.

$>$ More researches are required to understand the complex link between ICTs, learning and achievement. Besides, constant monitoring and evaluation on the use of ICT in Education and its outcome also become very essential.

\section{END NOTE:}

Despite an increase in number of institutions and enrolment of students in India, there is lack of quality in higher education and research. Higher educational institutions and enrolment of the students are steadily increasing by leaps and bounds year after year. Private sectors are performing better than public sectors. Expenditure on higher education in India is low as compared with other countries. Trade in higher education is already taking-place through the movement of students, teachers, programmes and even institutions. Global trade in higher education is large; it is estimated at more than US dollar 30 billion per annum. The major exporters of education are the USA, UK, Canada, New Zealand and Australia. China, India, the Philippines, and Indonesia are the major importers. Therefore, improvement of quality in higher education is the need of the hour to attract more students and teachers of home country and the rest of the world as well. This will promote competition in the market which will in turn entail the improvement of quality educational services being exchanged between the home country and abroad. Identifying root causes of declining the growth of quality education and research and initiating suitable measures in time by the Government will only bridge the existing educational gap between the producers and consumers in the long run. Educators and Policy makers are expected to keenly address the key issues of ICT and Education timely to uphold the knowledge economy in the country.

The consumers (Students) of today will become the producers (Teachers/Policy Makers) of tomorrow. Hence, promoting the quality of education and research in Higher Educational System and successful marketing of this service by using ICT in education to satisfy the targeted masses within and outside the country shall alone covert the dreams of today into reality in the days to come!.

\section{References:}

[1]. Agarwal, Pawan, 2006. "Higher Education in India: A Need for Change". ICRIER Working Paper, June, 2006.

[2]. Dreze. J. \&AmartyaSen, 1998. "India: Economic Development and Social Opportunity". Oxford University Press.

[3]. Smith Adam, 1776, "An Inquiry into the Nature and Causes of the Wealth of Nations, published in R.H. Campbell and A.S. Skinner(eds.), Adam Smith: An Inquiry into the Nature and Causes of the Wealth of Nations. (Oxford: Clarendon, 1976).

[4]. Consultation paper on Trade in Education Services, published by the Trade Policy Division, Department of Commerce, Government of India.

[5]. Report of UGC on Higher Education in India at a Glance, 2011 